Website: https://ojs.unikom.ac.id/index.php/common

DOI Jurnal: https://doi.org/10.34010/common

DOI Artikel: https://doi.org/10.34010/common.v4i1.2253

\title{
REPRESENTASI PERAN IBU DALAM IKLAN (ANALISIS SEMIOTIKA PADA IKLAN BERTEMA HARI IBU)
}

\begin{abstract}
Birda Mudafiuddin
Program Studi Ilmu Komunikasi, Fakultas Komunikasi dan Informatika, Universitas Muhammadiyah Surakarta, Jalan A. Yani, Mendungan, Pabelan, Kartasura, Kabupaten Sukoharjo, Jawa Tengah, Indonesia 57162

E-Mail:

daadeedaa23@gmail.com

Abstract

Advertising is a complex communication pattern that moves towards goals and uses strategies that influence the thoughts, feelings, and behavior of consumers. This study aims to describe the meaning of the Role of Mother contained in YouTube advertisements in December 2017 with the theme "Mother's Day". The research method used is descriptive-qualitative data analysis techniques using the semiotic analysis of Roland Barthes using the terms denotation, connotation and myth to find out the meaning of the values of the mother's role in the ad. Whether the results of the analysis of this study are indicative of the understanding of motherism in advertisements conducted by researchers. This understanding of motherism is marked by symbols of Mother's role as educators, sources of affection and a person who supports double.
\end{abstract}

Keywords: Mother's Role, Representation, Motherism and YouTube Advertising.

\begin{abstract}
Abstrak
Advertising merupakan pola komunikasi yang kompleks yang bergerak menuju tujuan dan menggunakan strategi dalam mempengaruhi pikiran, perasaan, dan perilaku konsumen. Penelitian ini bertujuan untuk mendeskripsikan makna Peran Ibu yang terkandung didalam empat iklan YouTube pada Desember 2017 yang bertema "Hari Ibu". Metode penelitian yang digunakan adalah deskriptif-kualitatif dengan teknik analisis data menggunakan analisis semiotik Roland Barthes yang menggunakan istilah denotasi, konotasi dan mitos untuk mengetahui makna tanda nilai-nilai Peran Ibu yang ada di iklan tersebut. Adapun hasil analisis penelitian ini adalah adanya indikasi paham ibuisme dalam iklan-iklan peneliti lakukan. Paham ibuisme ini ditandai dengan simbol-simbol Peran Ibu sebagai seorang pendidik, sumber kasih sayang dan seorang yang berperan ganda.
\end{abstract}

Kata Kunci: Peran Ibu, Representasi, Ibuisme Dan Iklan YouTube. 


\section{Pendahuluan}

\subsection{Latar Belakang}

Iklan adalah hasil dari kerja keras dan inspirasi, serta produk dari pemikiran yang logis dan jelas. Strategi persuasif dalam iklan tidak hanya sekedar mengiklankan suatu produk, tetapi juga mengarah pada citra atau nilai produk. Biasanya, iklan bertujuan untuk mengangkat fenomena sosial yang sedang marak di masyarakat sebagai topik iklan untuk kemudian ditampilkan secara eksplisit (Mabruri, 2013). Selain itu, untuk lebih menarik perhatian, iklan dibuat agar mampu mewakili perasaan penonton. Serta mampu mengilustrasikan kejadian yang pernah dialami oleh seseorang maupun mengilustrasikan sebuah kehidupan atau fakta yang terjadi (Mabruri, 2013).

Ide terhadap kehidupan perempuan dalam media tidak pernah habis untuk disampaikan. Kemampuan media, terutama iklan dalam bekerja menggunakan sebuah ide, kreativitas dan inspirasi yang tinggi untuk mengangkat persoalan perempuan yang berasal dari fenomena sosial yang berkembang ditengah masyarakat. Kehadiran perempuan dalam media di posisikan inferior dan menempati ruangruang domestik praktis sudah menjadi ciri ditengah maraknya industri media (Muwarni, 2018). Citra perempuan dalam iklan terlihat rendah dengan visualisasi yang nemempatkan perempuan dalam dikotomi publik versus domestik. Bahkan dalam masalah prinsip, citra perempuran dilihat dari kodrat kelahirannya. Fungsi perempuan dalam keluarga ditentukan dari sudut pandang bagaimana dirinya mampu mengelola sektor domestik seperti merawat, membesarkan, mengasuh, dan memberi perlindungan kepada anggota keluarga lainnya (Muwarni, 2018). Peran perempuan yang diiklankan dalam upaya pembentukan citra produk seringkali menggunakan tanda atau bahasa dalam masyarakat. Representasi perempuan dalam iklan selalu tersubordinasi secara sosial, yakni di wilayah domestik seperti mengasuh anak dan keluarga (Siswati, 2014).

Di masyarakat Indonesia saat ini, kelaziman terhadap pola asuh yang diterapkan oleh seorang ibu terbentuk dari hasil konstruksi sosial yang terjadi di masyarakat. Pada zaman dulu, seorang ibu hanya terkait dengan hal - hal mengenai rumah tangganya seperti: mendidik anak, merawat dan mengelola kebersihan serta keindahan rumah tangganya saja (Nafriandi, 2016). Menurut Wulansari (2009), peran adalah suatu konsep mengenai apa yang harus dilakukan oleh individu dalam masyarakat serta meliputi tuntutan-tuntutan perilaku dari masyarakat yang akan diemban dan dipertanggung jawabkan. Apabila seseorang dapat melaksanakan hak-hak dan kewajibannya sesuai dengan status yang dimilikinya, maka dapat dikatakan bahwa ia telah menjalankan peranannya. Duverger (2010) berpendapat bahwa setiap orang adalah pelaku didalam masyarakat dimana dia hidup, juga dia adalah seorang aktor yang harus memainkan beberapa peranan seperti aktor-aktor profesional.

Di sisi lain, dampak dari perkembangan zaman berbanding lurus dengan simbol dan tanda terhadap representasi perempuan. Semakin berkembangnya zaman semakin banyak pula simbol dan tanda yang baru. Hal ini diperkuat dengan kenyataan yang menjelaskan bahwa peran perempuan mengalami kemajuan dalam berbagai bidang. Meningkatnya jumlah perempuan ke wilayah publik dengan jenis pekerjaan dan posisi yang beragam (Indrayanti \& Lisna, 2007). Dari penjelasan di atas, serta melihat bagaimana perempuan dicitrakan dalam media serta mempertimbangkan perkembangan dan kemajuan perempuan 
Website: https://ojs.unikom.ac.id/index.php/common

DOI Jurnal: https://doi.org/10.34010/common

DOI Artikel: https://doi.org/10.34010/common.v4i1.2253

dalam dunia publik. Maka seperti pada beberapa iklan YouTube yang bertema hari ibu berikut akan menjadi objek penelitian dalam penelitian ini.

Iklan yang dibuat oleh Johnson's Baby Indonesia, menceritakan seorang wanita yang berkarir diharapkan untuk menyeimbangkan antara karir dengan kehidupan rumah tangga. Keseimbangan ini yang menciptakan citra super dalam sosok seorang ibu. Ia bekerja di dua ruang sekaligus, ruang publik dan domestik. Ia dapat bekerja dan membantu keuangan keluarga seperti seorang ayah. Di sisi lain, ia tetap memberikan kelembutan dan kasih sayang seorang ibu.

Iklan lain dari Bukalapak dengan judul Video Hari Ibu: Terima Kasih Ibu. Secara visual, iklan ini menampilkan dua sosok ibu. Yakni ibu kandung dan seorang asisten rumah tangga, yang dipanggil "bibi". Tokoh ibu dan bibi pada iklan ini samasama melakukan hal yang menjadi kewajibannya. Tokoh ibu mampu menjalankan tugas sebagai ibu dengan baik. Hal ini terlihat ketika tokoh ibu berusaha untuk menyuapkan makanan ke tokoh anak laki-laki, membantu menyiapkan makanan, menyediakan waktunya untuk bermain setelah pulang kerja. Sedangkan bibi yang dalam ini bisa dikatakan sebagai sosok ibu kedua bagi tokoh anak laki-laki. Diceritakan bibi tersebut bekerja di sebuah rumah yang bertugas membantu pekerjaan rumah yang dikerjakannya. Bibi tersebut tidak hanya berperan dan bertugas sebagai asisten rumah tangga, akan tetapi bibi tersebut juga berperan sebagai ibu kedua ketika tokoh anak laki-laki dari pemilik rumah sedang berada didekatnya. Bibi tersebut melindungi serta menjadi sosok yang diperlukan oleh si anak. Iklan ini memperlihatkan bagaimana peran seorang ibu yang dipraktikkan oleh dari tokoh ibu dan bibi.

Selanjutnya pada iklan yang dibuat oleh Supermi Indofood dengan judul
Supermi Hari Ibu. Iklan ini mengisahkan seorang ibu yang sangat interaktif dengan anak-anaknya. Mulai dari membantu menata rambut, bermain bola bersama anak hingga mengajari anak membuat suatu karya seni. Pekerjaan rumah tangga juga terlihat ketika sang ibu mencuci baju dan memasak untuk keluarganya. Iklan ini juga memperlihatkan aktivitas-aktivitas yang dilakukan oleh tokoh ibu.

Dalam iklan Selamat Hari Ibu yang diproduksi oleh Tupperware Indonesia. Iklan ini menceritakan dua kehidupan antara tokoh ibu dengan tokoh anak perempuan. Serta tokoh nenek dengan tokoh ibu. Kehidupan tokoh ibu dengan tokoh anak perempuan berbanding terbalik dengan kehidupan tokoh nenek dengan tokoh ibu. Ketika tokoh nenek mampu sabar dalam menghadapi tokoh ibu. Tetapi tokoh ibu tidak bisa langsung sabar ketika menghadapi tokoh anak perempuan. diceritakan kehidupan seorang ibu yang curhat kepada neneknya melalui surat. Ketika tokoh nenek hanya tersenyum melihat kebandelan tokoh ibu. Tetapi tokoh ibu merasa sedikit kesal melihat kebandelan tokoh anak perempuan. Iklan ini juga menjelaskan peran ibu dari dua kehidupan yang berbeda.

Iklan-iklan di atas sangat tertarik untuk diteliti. Adapun alasannya adalah keempat iklan tersebut mampu memanfaatkan momen Hari Ibu, sehingga menunjukkan bagaimana sosok ibu dalam lingkup Hari Ibu di Indonesia. Maka dari itu peneliti mengambil konsep peran ibu yang terpresentasikan dalam keempat iklan tersebut dan akan dianalisis dengan teori Ibuisme.

\subsection{Rumusan Masalah}

Rumusan masalah dalam penelitian ini adalah bagaimana representasi peran ibu yang terbentuk dalam iklan bertema hari ibu? 


\subsection{Tujuan}

Penelitian ini berusaha untuk mengetahui bagaimana iklan mampu merepresentasikan pesan tentang peran ibu. Penelitian ini hanya berfokus pada dialog dan visualisasi iklan bertema hari ibu.

\section{Kajian Pustaka dan Kerangka Pemikiran}

\subsection{Iklan Sebagai Media Komunikasi Massa}

Liliweri (2011) menjelaskan bahwa komunikasi massa adalah bentuk komunikasi yang menggunakan media dalam menyalurkan komunikator dan komunikan secara masal, heterogen, jangkauan luas dan menimbulkan efek. Advertising merupakan bentuk komunikasi massa. Kekuatan advertising yang utama adalah kemampuan menjangkau audiensi dalam jumlah yang sangat banyak (Moriarty, Nancy, dan William, 2018). Media massa sebagai jembatan komunikasi untuk komunikan yang tidak diketahui keberadaannya dan tersebar. Media massa merupakan sebuah alat yang digunakan untuk menyampaikan pesan dari komunikator kepada komunikan seperti radio, surat kabar dan televisi. (Cangara, 2005 dalam Nida, 2014).

Namun seiring dengan berkembangnya zaman dan teknologi, media internet menjadi alat komunikasi massa. Internet sangat berkontribusi dalam arus informasi komunikasi massa karena semua media seperti surat kabar, radio, tv dapat juga diakses dengan internet seperti YouTube, radio streaming, koran online, dan sebagainya. Menurut Faiqah, Nadjib, dan Amir (2016) YouTube merupakan sebuah situs web sharing (berbagi video) yang menjadi populer dan mampu menjadi alat media perikalan. Media-media periklanan menurut Hair dan Lamb dalam Prasetyo, dkk (2016) antara lain televisi, internet, media luar ruang, radio, majalah, dan koran.

Advertising adalah sebuah pola komunikasi yang kompleks yang bergerak menuju tujuan dan menggunakan strategi dalam mempengaruhi pikiran, perasaan, dan perilaku konsumen (Moriarty, Nancy, dan William, 2018). Sedangkan menurut ahli lain menyebutkan advertising merupakan kegiatan komunikasi pemasaran yang menggunakan media massa dalam proses penyampaian pesannya (Soemanagara, Rd 2006). Moriarty, Nancy, dan William (2018) menjelaskan bahwa iklan korporat merupakan tipe lain dari advertising yang dipakai perusahaan untuk memperkaya atau menjaga reputasi dikalangan audiensi tertentu atau untuk membangun kesadaran akan nama perusahaan dan sifat bisninya.

Dalam sebuah penelitian dengan judul Representasi Perempuan Pada Iklan Televisi Dancow Calcium Plus Versi More Than A Woman oleh Wijaya (2013). Penelitian ini melihat iklan sebagai media massa, karena iklan yang ditayangkan digunakan pemasar untuk menjangkau konsumen dan menyampaikan pesannya. Hasil penelitian ini menyimpulkan bahwa iklan tersebut cenderung menunjukkan bias gender modern yakni konstruksi sosial yang menggiring perempuan menuju sosok tradisional dalam lingkup modern dan adanya pencampuran ideologi-ideologi tradisional dan modern pada masyarakat patriarkat. Perbedaan penelitian ini dengan penelitian penulis terdapat pada pendekatan semiotika dan objek.

\subsection{Representasi Ibu di Media}

Representasi menurut Hall (2003) merupakan sebuah makna yang dihasilkan dan dipertukarkan dalam masyarakat, 
Website: https://ojs.unikom.ac.id/index.php/common

DOI Jurnal: https://doi.org/10.34010/common

DOI Artikel: https://doi.org/10.34010/common.v4i1.2253

dengan kata lain representasi ialah salah satu cara untuk memproduksi makna. Selain itu Hall (2003) menambahkan bahwa konsep dan tanda merupakan bagian penting dalam memproduksi makna. Sehingga bisa ditarik kesimpulan bahwa representasi merupakan makna yang disampaikan dengan bahasa dan telah diproduksi dari konsep yang berada dalam pikiran manusia. Secara sederhana, representasi merupakan gambaran terhadap suatu hal yang berada dalam kehidupan dan digambarkan melalui suatu media (Barker, 2008 dalam Vera).

Suryakusuma (2011) menjelaskan bahwa ibuisme digambarkan sebagai konsep ibu negara Indonesia lebih dari sekedar kepada keibuan biologis, yakni perempuan kaya, perempuan yang memiliki keahlian, memiliki kedudukan sosial, memiliki keahlian, memiliki kekuatan spiritual, perempuan asing, perempuan tua, bahkan perempuan yang tidak memiliki anak bisa disebut "ibu". Ibuisme ini memiliki ruang lingkup yang lebih luas melebihi domestifikasi.

Suryakusuma (2011) menambahkan bahwa ibu yang ideal dalam paham ibuisme adalah perempuan-perempuan yang wajib melayani keluarga, anak, suami, masyarakat dan negara. Suryakusuma (2011) juga menjelaskan jenis-jenis kegiatan perempuan secara umum, yakni kegiatan yang berpenghasilan, kegiatan domestik dan keluarga serta kegiatan sosial dan masyarakat. Dengan demikian perempuan dianggap tidak hanya bertanggung jawab pada urusan keluarga secara rohani, tetapi juga untuk mensejahterakan material dalamm keluarga. Selanjutnya Suryakusuma (2011) menjelaskan bahwa aturan-aturan dalam ruang domestik memberi ruang kepada perempuan untuk mengekspresikan realitas kehidupan mereka.

Adapun penelitian yang menjadi referensi dan memiliki keterikatan dengan penelitian ini adalah sebuah penelitian yang berjudul Represetasi Perempuan Dalam Majalah Wanita oleh Wiratmo dan Gifari (2008), dikatakan bahwa seorang perempuan yang berhasil dan mampu mempertahankan eksistensinya, juga mampu menjaga tanggungjawabnya sebagai seorang ibu terhadap keluarga dan anak-anaknya.

Peran ibu juga dibahas dalam sebuah penelitian yang berjudul Bias Gender dalam Iklan Attack Easy di Televisi oleh Rahmawati (2010). Hasil temuan penelitian ini adalah perempuan berfungsi sebagai istri dan ibu rumah tangga. Perempuan yang mengelola rumah tangga atau mengurus peran domestik dan dikatakan bahwa perempuan tersebut bersifat mulia dan berbudi luhur.

Penelitian selanjutnya berjudul Representasi Domestifikasi Perempuan dalam Iklan oleh Endah Siswati (2014), temuan dalam penelitian ini adalah adanya kecenderungan perempuan yang direpresentasikan dengan tema dan cara bias gender. Tema dan cara representasi perempaun dalam iklan ini adalah perempuan sebagai seorang istri dan ibu rumah tangga serta perempuan yang menarik secara visual.

Dalam penelitian yang berjudul Media Massa dan Representasi Perempuan dalam Iklan oleh Fazri dan Hartati (2018), dikatakan bahwa representasi perempuan dalam iklan susu formula SGM menunjukkan perempuan sebagai ibu rumah tangga. Ibu rumah tangga yang mempersiapkan dan melakukan semua hal untuk kebutuhan keluarga. Perempuan menunjukkan sebuah peran yang hanya berfungsi dirumah. Sehingga ini memberikan bukti bahwa perempuan yang banyak ditampilkan dalam dunia periklanan ini lebih menunjukkan peran perempuan hanya terpaut dalam konteks rumah saja.

Dalam penelitian lain yang berjudul Domestifikasi Perempuan Dalam Iklan 
Website: https://ojs.unikom.ac.id/index.php/common

DOI Jurnal: https://doi.org/10.34010/common

DOI Artikel: https://doi.org/10.34010/common.v4i1.2253

Produk Perawatan Bayi dan Anak oleh Endah Muwarni (2018), dikatakan bahwa penggambaran perempuan yang menjalankan domestifikasi sebagai mendidik, merawat dan mengasuh anakanaknya, mengurus rumah tangga. Penggambaran perempuan dalam penelitian ini menunjukkan nilai-nilai ideologi pengibuan yang sudah melekat pada masyarakat.

\subsection{Semiotika Roland Barthes}

Menurut Daniel Chandler dalam Vera (2014), semiotika adalah ilmu tentang tanda-tanda. Charles Sanders Pierce juga berpendapat terhadap definisi semiotika, bahwa semiotika merupakan studi tentang tanda dan segala sesuatu yang berhubungan dengannya, yakni fungsi, hubungan dengan tanda-tanda lain serta pengiriman dan penerimaannya dalam menggunakannya. Preminger juga berpendapat bahwa semiotika merupakan sebuah ilmu tentang tanda-tanda.

Dalam penelitiannya Barthes menggunakan tiga hal inti, yakni denotatif, konotatif dan mitos. Denotatif menjelaskan makna yang terlihat secara nyata. Konotatif menjelaskan makna yang tersembunyi dibalik tanda-tanda dan bersifat tersirat. Sedangkan Mitos muncul dan berkembang dalam benak masyarakat karena penafsiran yang dilakukan oleh masyarakat terhadap sesuatu. Masyarakat menafsirkannya dengan cara memperhatikan dan memaknai hubungan timbal balik antara apa yang terlihat secara nyata (denotasi) dengan tanda apa yang tersirat dari hal tersebut (konotasi) (Ismujihastuti \& Mahadian, 2015).

Sebuah penelitian pernah diteliti oleh Ilona Oisinia Situmeang tahun 2015 dengan judul Representasi Wanita Pada Iklan Televisi Wardah Cosmetic (Analisa Semiotik Roland Barthes Wardah Inspiring Beauty Versi True Colours). Dalam penelitian tersebut menyimpulkan bahwa denotasi pada iklan tersebut adalah adanya beberapa perempuan cantik yang mengkonsumsi kosmetik wardah dan menjadi perempuan Indonesia dengan rasa percaya diri. Selanjutnya konotasi pada penelitian ini adalah perempuanperempuan dapat menyampaikan motivasi serta memberikan inspirasi kepada orang lain, karena perempuan yang cantik itu tidak hanya dinilai dan terlihat dari fisik, melainkan perempuan yang senyum bisa dikatakan sebagai wanita cantik. Sedangkan mitosnya adalah perempuan yang cantik ialah perempuan yang memiliki hati yang baik dan perempuan yang mampu membagikan motivasi dan inspirasi kepada orang lain merupakan perempuan cantik. Perbedaan penelitian di atas dengan penelitian yang akan peneliti lakukan terletak pada makna perempuan yang ingin dipresentasikan serta jenis iklan dan objek penelitian.

\section{Objek dan Metode Penelitian}

Metode yang digunakan dalam penelitian ini yaitu metode semiotika dengan pendekatan Roland Barthes. Teknik sampling yang digunakan adalah purposive sampling, yakni memilih sampel dengan pertimbangan sampel yang dianggap sebagai 'kunci' dan mengutamakan tujuan penelitian daripada populasi dalam menentukan sampel (Bungin, 2013). Peneliti memilih sampel berdasarkan karakter yang mempunyai peran ibu.

Teknik pengumpulan data pada penelitian ini yakni menggunakan teknik dokumentasi, untuk memperoleh data dan informasi dalam bentuk buku, arsip, dokumen, tulisan angka dan gambar yang berupa laporan serta keterangan yang dapat mendukung penelitian (Sugiyono, 2012). Studi Pustaka berkaitan dengan kajian teoritis dan referensi lain yang berkaitan dengan nilai, budaya dan norma yang 
Website: https://ojs.unikom.ac.id/index.php/common

DOI Jurnal: https://doi.org/10.34010/common

DOI Artikel: https://doi.org/10.34010/common.v4i1.2253

berkembang pada situasi sosial yang diteliti, selain itu studi kepustakaan sangat penting dalam melakukan penelitian, hal ini dikarenakan penelitian tidak akan lepas dari literatur-literatur ilmiah (Sugiyono, 2012).

Populasi iklan bertema hari ibu di bulan Desember 2017 berjumlah 14 iklan, yang kemudian peneliti ambil menjadi beberapa sampel. Dengan menggunakan purposive sampling, peneliti memilih sampel dengan pertimbangan sampel yang dianggap sebagai "kunci" dan penelitian lebih mengutamakan tujuan penelitian daripada populsai dalam menentukan sampel (Bungin, 2013). Pertimbangan atau unsur sampling tersebut diantaranya: 2 iklan dengan likes terbanyak dan 2 iklan dengan viewers terbanyak.

Dalam penelitian ini, peneliti menentukan unit analisis, yakni unit-unit atau satuan-satuan yang akan dianalisis dalam penelitian, yaitu peneliti hanya menganalisis unit, scene dengan tanda peran ibu pada iklan berdasarkan sampel secara visual. Teknik analisis data yang digunakan yaitu teknik analisis kualitatif melalui metode semiotika Roland Barthes untuk mengetahui makna peran ibu dalam iklan bertema hari ibu, yang menggunakan penekanan pada pemaknaan dari suatu sistem tanda (kode) melalui sistem pemaknaan tingkat pertama atau yang biasa disebut dengan denotasi, selanjutnya ke sistem pemaknaan tingkat kedua yang disebut konotasi dan yang terakhir berupa penjelasan mitos mengenai peran ibu (Ismujihastuti \& Mahadian, 2015).

Dalam penelitian ini, peneliti menggunakan teknik validitas data yaitu teknik triangulasi data dan triangulasi teori. Triangulasi data digunakan untuk meyakinkan data-data yang ada dalam penelitian ini adalah valid. Maka dari itu peneliti menggunakan data dan teori konsep sebagai teknik validitas datanya. Untuk triangulasi data, data yang di dapat dari dokumentasi empat iklan YouTube.
Sedangkan, triangulasi teori dilakukan dengan membandingkan atau mencocokkan teori-teori yang digunakan dengan temuan yang diperoleh. Teori konsep yang digunakan dalam penelitian ini yaitu menggunakan teori konsep Ibuisme yang dikaitkan dengan konsep peran ibu (Pawito, 2007).

\section{Hasil dan Pembahasan}

Untuk menganalisa representasi peran ibu dalam iklan bertema hari ibu, peneliti memilih beberapa adegan yang menunjukkan peran ibu, yang kemudian akan dianalisis menggunakan semiotika Roland Barthes. Peneliti membagi dalam beberapa kategori yang merepresentasikan peran ibu pada tokoh ibu dalam iklan. Peneliti menganalisa melalui tanda-tanda dan dialog yang terdapat dalam adegan tersebut.

\subsection{Ibu Sebagai Pendidik Anak}

Iklan yang dibuat dengan tema hari ibu sebenarnya tidak hanya sebagai apresiasi atau merayakan hari ibu sendiri. Namun terdapat sebuah pesan-pesan yang berkaitan dengan peran ibu dalam iklan sedang diteliti oleh peneliti. Menurut Kamus Besar Bahasa Indonesia (KBBI) Daring, mendidik berarti memelihara dan memberi latihan (ajaran, tuntunan, pimpinan). Upaya dan tanggung jawab terhadap kebutuhan dan pemenuhan hak anak menjadi tugas orang tua dalam memenuhi hak. Dalam kapasitasnya, seorang ibu memiliki peran yang harus dijalankan. Menurut Novrinda, Nina, dan Yulidesni (2017), pemenuhan hak anak meliputi upaya dan tindakan yang dilakukan oleh orang tua yakni proses perawatan, pengasuhan, dan pendidikan anak. Peran ibu sebagai pendidik anak ditunjukkan dalam scene di bawah ini: 
Website: https://ojs.unikom.ac.id/index.php/common

DOI Jurnal: https://doi.org/10.34010/common

DOI Artikel: https://doi.org/10.34010/common.v4i1.2253

Gambar 1.

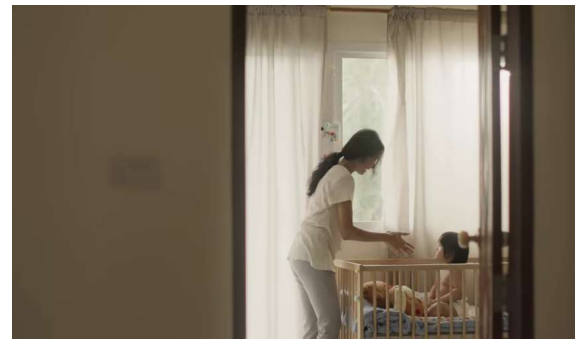

Tabel 1.

\begin{tabular}{|c|c|}
\hline Signifier Denotative & Signified Denotative \\
\hline $\begin{array}{l}\text { Scene tokoh ibu sedang } \\
\text { berinteraksi dengan tokoh anak } \\
\text { dalam iklan Johnson's Baby } \\
\text { Indonesia. }\end{array}$ & $\begin{array}{l}\text { Dalam scene tersebut, tokoh ibu } \\
\text { terlihat berambut hitam } \\
\text { bergelombang dengan model } \\
\text { diikat. Tokoh ibu mengenakan } \\
\text { kaos putih serta celana panjang } \\
\text { berwarna abu-abu sedang } \\
\text { mencoba mengajak tokoh anak } \\
\text { untuk digendong. Tokoh anak } \\
\text { perempuan terlihat berambut } \\
\text { lurus pendek berwarna hitam. } \\
\text { Tokoh anak peremuan } \\
\text { mengenakan celana pendek dan } \\
\text { sedang melihat tokoh ibu. } \\
\text { Kedua tokoh tersebut sedang } \\
\text { berada di kamar tokoh anak } \\
\text { perempuan yang diperlihatkan } \\
\text { adanya pintu dan ranjang dan } \\
\text { jendela. }\end{array}$ \\
\hline Signifier Conotative & Signified Conotative \\
\hline $\begin{array}{l}\text { Di pagi hari yang cerah, tokoh } \\
\text { ibu menuju kamar tokoh anak } \\
\text { perempuan. Kemudian tokoh } \\
\text { ibu menggendong, memandikan } \\
\text { dan memakaikan pakaian } \\
\text { sehingga tokoh anak perempuan } \\
\text { terlihat cantik. }\end{array}$ & $\begin{array}{l}\text { Melalui scene ini dapat } \\
\text { diketahui bahwa tokoh ibu } \\
\text { terlihat sebagai pendidik anak. } \\
\text { Hal tersebut terlihat karena } \\
\text { tokoh ibu sedang berinteraksi } \\
\text { dengan tokoh anak perempuan. } \\
\text { Tokoh ibu sedang mengajak } \\
\text { anak tersebut untuk bersih- } \\
\text { bersih diri di pagi hari. }\end{array}$ \\
\hline
\end{tabular}

Menurut Putri dan Lestari (2015) mendidik anak merupakan tanggung jawab seorang ibu karena ibu lebih banyak memiliki waktu untuk mengawasi dan mendidik anak. Berdasarkan gambar 4.1 seorang ibu yang berusaha berinteraksi dengan anak, menggendong, memandikan dan memakaikan pakaian merupakan bentuk tanggung jawab ibu untuk mendidik anak. Dalam scene di atas tokoh ibu memiliki banyak waktu dengan tokoh anak, yang di buktikan dengan berinteraksi yang kemudian di lanjutkan dengan menggendong tokoh anak, memandikannya dan membantu mengenakan pakaian kepada tokoh anak.

Dalam sebuah penelitian oleh Putri dan Lestari (2015), menyebutkan pembagian dalam mengasuh anak merupakan tugas orang tua sehingga suami dan istri bekerjasama mampu menjalankan tanggungjawabnya. Suami istri akan bekerjasama, seperti bergantian mengingatkan hal baik kepada anak, memberikan nasihat, mengawasi anak dan mendidik anak. Temuan penelitian tersebut menunjukkan adanya pandangan bahwa pengasuhan dalam mendidik anak merupakan tanggung jawab seorang ibu. Lewin-Epstein \& Braun, (2006); Lee \& Waite, (2005) dalam Putri dan Lestari (2015) menjelaskan rata-rata suami mampu berkontribusi dalam pekerjaan rumah tangga selama 18 jam per minggu, sedangkan istri 26 jam per minggu.

Gambar 2

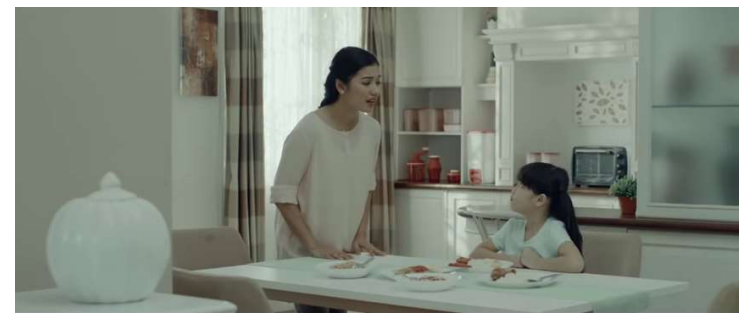

Tabel 2.

\begin{tabular}{|c|c|}
\hline Signifier Denotative & Signified Denotative \\
\hline $\begin{array}{l}\text { Scene tokoh ibu sedang } \\
\text { mengajak tokoh anak } \\
\text { perempuan untuk makan dalam } \\
\text { iklan Tupperware Indonesia. }\end{array}$ & $\begin{array}{l}\text { Dalam scene tersebut, tokoh ibu } \\
\text { terlihat berambut hitam panjang } \\
\text { bergelombang dengan model } \\
\text { dikepang. Tokoh ibu } \\
\text { mengenakan baju coklat muda } \\
\text { dan sedang merayu tokoh anak } \\
\text { perempuan untuk sarapan. } \\
\text { Tokoh anak perempuan terlihat } \\
\text { dengan rambut lurus dengan } \\
\text { model dikuncir kanan dan kiri } \\
\text { berwarna hitam. Tokoh anak } \\
\text { perempuan tersebut } \\
\text { mengenakan baju berwarna biru } \\
\text { muda dan sedang memerhatikan } \\
\text { tokoh ibu sambil menolak } \\
\text { sarapan dari tokoh ibu. Kedua } \\
\text { tokoh tersebut sedang berada } \\
\text { diruang makan, ditandai dengan } \\
\text { adanya meja makan berwarna }\end{array}$ \\
\hline
\end{tabular}


Website: https://ojs.unikom.ac.id/index.php/common

DOI Jurnal: https://doi.org/10.34010/common

DOI Artikel: https://doi.org/10.34010/common.v4i1.2253

\begin{tabular}{|c|l|}
\hline & $\begin{array}{l}\text { putih, kursi berwarna coklat, } \\
\text { lemari berwarna putih yang } \\
\text { disertai toples makanan } \\
\text { berwarna merah muda, putih, } \\
\text { dan oven kecil berwarna hitam. }\end{array}$ \\
\hline \multicolumn{1}{|c|}{ Signifier Conotative } & Signified Conotative \\
\hline $\begin{array}{l}\text { Tokoh ibu mengajak tokoh anak } \\
\text { untuk makan, tetapi tokoh anak } \\
\text { tidak mau. Meskipun tokoh ibu } \\
\text { terus mencoba dengan memberi } \\
\text { banyak makanan yang berbeda, } \\
\text { tokoh anak tetap tidak mau } \\
\text { untuk makan. }\end{array}$ & $\begin{array}{l}\text { Dalam scene di atas, tokoh ibu } \\
\text { Herlihat sebagai pendidik anak. } \\
\text { terus mencoba merayu bahwa } \\
\text { sarapan itu penting. }\end{array}$ \\
\hline
\end{tabular}

Pada gambar 4.2 tokoh ibu berusaha dan membujuk tokoh anak untuk makan. Usaha yang dilakukan oleh tokoh ibu adalah upaya pengasuhan dan usaha untuk melindungi anak agar tidak sakit. Bentuk dari pengasuhan dan melindungi adalah bagian dari mendidik. Fungsi perempuan dalam lingkup keluarga di tentukan oleh sudut pandang bagaimana perempuan tersebut mampu mengatur dan mengelola sektor domestik (rumah tangga), yaitu merawat, membesarkan, mengasuh, dan memberi perlindungan kepada anggota keluarganya (Muwarni, 2018). Dalam kewajiban memberikan pendidikan terhadap anak-anak merupakan sebuah kemuliaan tersendiri dan menjadi sebuah tolak ukur yang mutlak untuk menilai keberhasilan sebagai seorang ibu (Muwarni, 2018).

Gambar 3.

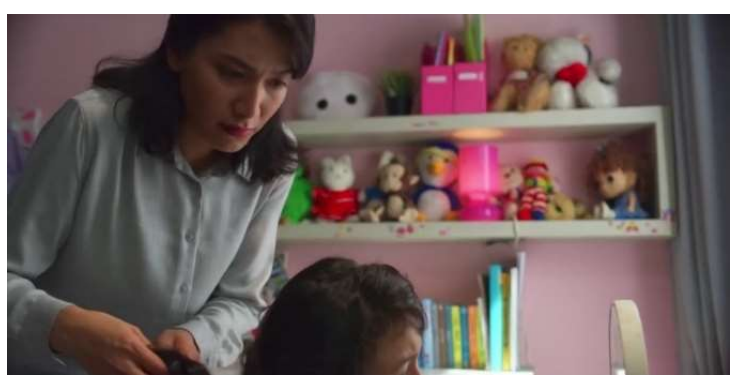

Tabel 3.

\begin{tabular}{|l|l|}
\hline \multicolumn{1}{|c|}{ Signifier Denotative } & \multicolumn{1}{c|}{ Signified Denotative } \\
\hline $\begin{array}{l}\text { Scene tokoh ibu yang sedang } \\
\text { menata rambut anaknya dalam } \\
\text { iklan Supermi Hari Ibu. }\end{array}$ & $\begin{array}{l}\text { Dalam scene tersebut, tokoh ibu } \\
\text { terlihat berambut pendek hitam } \\
\text { bergelombang dengan model } \\
\text { terurai. Tokoh ibu mengenakan } \\
\text { baju berwarna biru muda dan }\end{array}$ \\
\hline
\end{tabular}

\begin{tabular}{|c|c|}
\hline & $\begin{array}{l}\text { sedang menata rambut tokoh } \\
\text { anak perempuan. Sedangkan } \\
\text { tokoh anak perempuan terlihat } \\
\text { berambut coklat dan sedang } \\
\text { melihat rambutnya ditata oleh } \\
\text { tokoh ibu dengan cermin bundar } \\
\text { yang berada didepannya. Kedua } \\
\text { tokoh tersebut berada didalam } \\
\text { kamar tokoh anak perempuan, } \\
\text { yang ditandai dengan dinding } \\
\text { berwarna merah muda. Terdapat } \\
\text { rak dinding berwarna putih yang } \\
\text { diisi dengan berbagai macam } \\
\text { boneka, lampu tidur berwarna } \\
\text { merah muda. Dibawah rak } \\
\text { dinding ada meja berwarna } \\
\text { putih yang di atasnya ada } \\
\text { beberapa buku yang sudah } \\
\text { tertata rapi. }\end{array}$ \\
\hline Signifier Conotative & Signified Conotative \\
\hline $\begin{array}{l}\text { Tokoh ibu sedang menata } \\
\text { rambut anak di dalam kamar } \\
\text { tokoh anak perempuan dengan } \\
\text { serius. Tokoh ibu mencoba } \\
\text { berbagai model dengan melihat } \\
\text { referensi di internet. Sedangkan } \\
\text { tokoh anak perempuan terus } \\
\text { memerhatikan rambutnya } \\
\text { dengan melihat cermin bundar } \\
\text { yang dipegangnya. }\end{array}$ & $\begin{array}{l}\text { Dalam gambar } 4.3 \text { tokoh ibu } \\
\text { dapat diketahui sebagai sosok } \\
\text { pendidik anak. Hal tersebut } \\
\text { terlihat karena tokoh ibu sedang } \\
\text { membantu tokoh anak. Tokoh } \\
\text { ibu membantu tokoh anak } \\
\text { sebagai pemberi semangat } \\
\text { belajar yang merupakan bentuk } \\
\text { pendidikan yang dilakukan oleh } \\
\text { para ibu (Pidarta, 1997). }\end{array}$ \\
\hline
\end{tabular}

Pidarta (1997) menjelaskan biasanya ungkapan pendidikan utama dan pertama adalah keluarga dan yang menjadi peran utama adalah seorang ibu. Pada gambar 4.3 tokoh ibu membantu tokoh anak mengepang rambut. Bentuk kegiatan tokoh ibu kepada anak merupakan sebuah pendidikan dalam menangani hal-hal yang bersifat keterampilan. Dalam penelitiannya Pidarta (1997) juga menjelaskan bentuk pendidikan yang dilakukan oleh ibu berdasarkan informan adalah pendidikan budi pekerti $(29,7 \%)$ dan pendidikan praktis $(25,7 \%)$. Dari segi fasilitas pendidikan dan alat belajar ada alat-alat keterampilan (10,8\%).

Tokoh ibu dalam gambar 4.3 mencoba mendidik anak dengan kemandirian anak. Fitriyani, Nunung dan Sahadi (2016) menjelaskan bahwa salah satu kebutuhan dasar seorang anak adalah kebutuhan pendidikan yang melibatkan proses kemandirian anak, berbahasa, berpikir, dan sosialisasi.

Mitos dalam scene-scene di atas adalah mendidik anak merupakan peran seorang 
ibu. Seorang ibu memiliki waktu yang lebih banyak dalam mendidik dan mengawasi anak. Hal ini ditegaskan oleh Suryakusuma (2011) bahwa bentuk hubungan anak dan seorang ibu dimulai dari mengandung, melahirkan, menyusui, sampai memelihara bayinya. Seorang ibu akan selalu melindungi, mengatur dan mengelola sektor domestik. Suryakusuma (2011) mengatakan seorang ibu harus bisa menjadi pilar bangsa. Yakni peran perempuan sebagai seorang induk dalam keluarga. Dalam mendidik anak, membantu kemandirian anak merupakan bentuk pendidikan seorang ibu. Dalam ibuisme oleh Suryakusuma (2011) dijelaskan masyarakat telah mempunyai konstruksi perempuan yang memiliki peran, yakni merawat keluarga, melayani suami, merawat anak, dan mengelola rumah tangga. Bentuk nilai-nilai tersebut berfungsi untuk melegitimasi domestifikasi bahwa ibu harus di rumah untuk mendidik anak. Sehingga itu menjadi menjadi mitos yang dipercaya dimasyarakat bahwa mendidik anak merupakan peran ibu. Pidarta (1997) menjelaskan biasanya ungkapan pendidikan utama dan pertama adalah keluarga dan yang menjadi peran utama adalah seorang ibu. Pada gambar 4.3 tokoh ibu membantu tokoh anak mengepang rambut. Bentuk kegiatan tokoh ibu kepada anak merupakan sebuah pendidikan dalam menangani hal-hal yang bersifat keterampilan. Dalam penelitiannya Pidarta (1997) juga menjelaskan bentuk pendidikan yang dilakukan oleh ibu berdasarkan informan adalah pendidikan budi pekerti $(29,7 \%)$ dan pendidikan praktis $(25,7 \%)$. Dari segi fasilitas pendidikan dan alat belajar ada alat-alat keterampilan (10,8\%).

Tokoh ibu dalam gambar 4.3 mencoba mendidik anak dengan kemandirian anak. Fitriyani, Nunung dan Sahadi (2016) menjelaskan bahwa salah satu kebutuhan dasar seorang anak adalah kebutuhan pendidikan yang melibatkan proses kemandirian anak, berbahasa, berpikir, dan sosialisasi.

Mitos dalam scene-scene di atas adalah mendidik anak merupakan peran seorang ibu. Seorang ibu memiliki waktu yang lebih banyak dalam mendidik dan mengawasi anak. Hal ini ditegaskan oleh Suryakusuma (2011) bahwa bentuk hubungan anak dan seorang ibu dimulai dari mengandung, melahirkan, menyusui, sampai memelihara bayinya. Seorang ibu akan selalu melindungi, mengatur dan mengelola sektor domestik. Suryakusuma (2011) mengatakan seorang ibu harus bisa menjadi pilar bangsa. Yakni peran perempuan sebagai seorang induk dalam keluarga. Dalam mendidik anak, membantu kemandirian anak merupakan bentuk pendidikan seorang ibu. Dalam ibuisme oleh Suryakusuma (2011) dijelaskan masyarakat telah mempunyai konstruksi perempuan yang memiliki peran, yakni merawat keluarga, melayani suami, merawat anak, dan mengelola rumah tangga. Bentuk nilai-nilai tersebut berfungsi untuk melegitimasi domestifikasi bahwa ibu harus di rumah untuk mendidik anak. Sehingga itu menjadi menjadi mitos yang dipercaya dimasyarakat bahwa mendidik anak merupakan peran ibu.

\subsection{Ibu Sebagai Sumber Kasih Sayang}

Menurut Djamarah (2004) kasih sayang dalam keluarga akan terjadi jika seluruh anggota keluarga merasakan kebahagiaan. Kondisi ini dibuktikan dengan berkurangnya kekecewaan, ketegangan dan menerima seluruh keadaan dan keadaan dirinya seperti mental, fisik dan sosial. Bukti kasih sayang keluarga meliputi saling pengertian, saling mendukung, mempunyai waktu bersama keluarga, adanya kerja sama dan adanya komunikasi tiap anggota (Djamarah, 2004). 
Website: https://ojs.unikom.ac.id/index.php/common

DOI Jurnal: https://doi.org/10.34010/common

DOI Artikel: https://doi.org/10.34010/common.v4i1.2253

Peran ibu sebagai sumber kasih sayang terdapat pada beberapa scene di bawah ini:

Gambar 4.

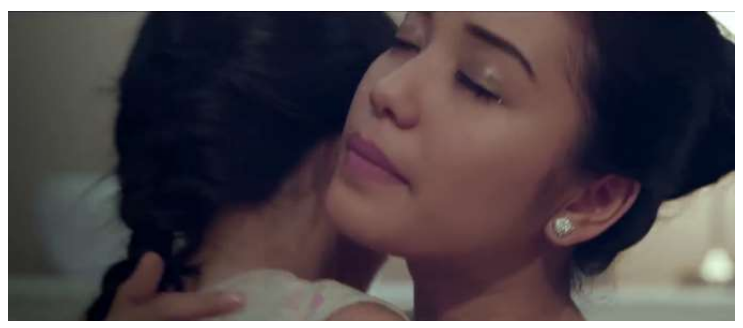

Tabel 4.

\begin{tabular}{|c|c|}
\hline Signifier Denotative & Signified Denotative \\
\hline $\begin{array}{l}\text { Scene tokoh ibu yang memeluk } \\
\text { tokoh anak perempuan dalam } \\
\text { iklan Tupperware Indonesia. }\end{array}$ & $\begin{array}{l}\text { Dalam scene tersebut, tokoh ibu } \\
\text { terlihat berambut pendek hitam } \\
\text { dengan model sanggul. Tokoh } \\
\text { ibu sedang memeluk tokoh anak } \\
\text { perempuan dengan rasa penuh } \\
\text { kasih sayang. Tokoh anak } \\
\text { perempuan terlihat berambut } \\
\text { panjang berwarna hitam dengan } \\
\text { model kepang satu dan sedang } \\
\text { memeluk tokoh ibu. }\end{array}$ \\
\hline Signifier Conotative & Signified Conotative \\
\hline $\begin{array}{l}\text { Tokoh anak perempuan } \\
\text { mengotak atik pekerjaan tokoh } \\
\text { ibu. Setelah tokoh ibu } \\
\text { mengetahuinya, seketika tokoh } \\
\text { ibu memarahi tokoh anak. } \\
\text { Setelah menyesal memarahi } \\
\text { tokoh anak, tokoh ibu langsung } \\
\text { memeluk tokoh anak dengan } \\
\text { penuh kasih sayang. }\end{array}$ & $\begin{array}{l}\text { Dalam gambar } 4.4 \text { tokoh ibu } \\
\text { memeluk tokoh anak dengan } \\
\text { penuh rasa kasih sayang. } \\
\text { Terlihat dari ekspresi yang di } \\
\text { perlihatkan tokoh ibu, memeluk } \\
\text { dengan mata tertutup. Hal ini } \\
\text { menunjukkan bahwa tokoh ibu } \\
\text { memberikan kasih sayangnya } \\
\text { kepada tokoh anak. Memeluk } \\
\text { seorang anak adalah simbol } \\
\text { kasih sayang (Muwarni, 2018). }\end{array}$ \\
\hline
\end{tabular}

Menurut Hyosymania (2011) orang tua yang baik adalah seorang komunikator dan pendengar yang baik, inti dari kasih sayang yang tercipta yakni dengan kualitas interaksi antar anggota keluarga. Pada gambar 4.4 tokoh ibu memeluk tokoh anak perempuan dengan tulus yang tandai dengan tertutupnya mata tokoh ibu. Pelukan yang dilakukan oleh tokoh ibu merupakan tanda kasih sayang yang diberikan tokoh ibu kepada tokoh anak perempuan. Dengan memeluk tokoh anak perempuan, tokoh ibu memberikan pesan atau mengkomunikasikan bahwa tokoh ibu memiliki rasa kasih sayang terhadap tokoh anak. Setiawan dalam Hyosymania (2011) menambahkan komunikasi yang efektif mampu membuat anak atau orang tua mudah dalam menyampaikan apa yang dirasakannya. Dengan demikian, orang tua mampu mengenali kepribadian anak dan mampu menjalin hubungan baik dengan anaknya.

Gambar 5.

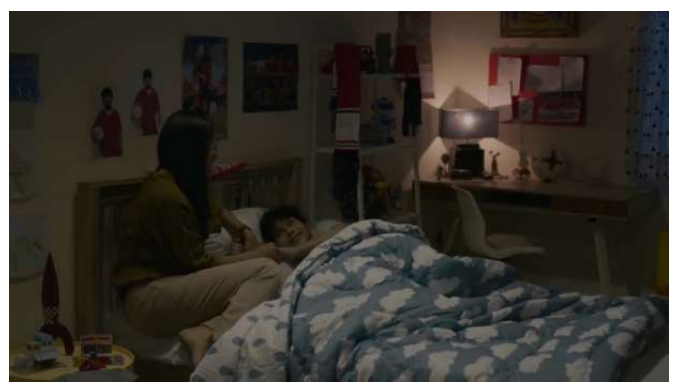

Tabel 5.

\begin{tabular}{|c|c|}
\hline Signifier Denotative & Signified Denotative \\
\hline $\begin{array}{l}\text { Scene tokoh ibu sedang } \\
\text { menemani tokoh anak laki-laki } \\
\text { dikamarnya dalam iklan } \\
\text { Bukalapak. }\end{array}$ & $\begin{array}{l}\text { Dalam scene tersebut, tokoh ibu } \\
\text { terlihat berambut hitam lurus } \\
\text { dan menggunakan baju } \\
\text { berwarna coklat serta } \\
\text { mengenakan celana panjang } \\
\text { berwarna krem. Tokoh ibu } \\
\text { tersebut sedang bersenda gurau } \\
\text { dengan tokoh anak laki-laki. } \\
\text { Tokoh anak laki-laki terlihat } \\
\text { berambut pendek tebal } \\
\text { berwarna hitam dan sedang } \\
\text { bersenda gurau dengan tokoh } \\
\text { ibu. Kedua tokoh tersebut } \\
\text { bersenda gurau di kamar tokoh } \\
\text { anak laki-laki. }\end{array}$ \\
\hline Signifier Conotative & Signified Conotative \\
\hline $\begin{array}{l}\text { Setelah pulang dari kerja, tokoh } \\
\text { ibu segera menemui anaknya. } \\
\text { Kemudian tokoh anak laki-laki } \\
\text { menyabut tokoh ibu dengan } \\
\text { gembira. }\end{array}$ & $\begin{array}{l}\text { Pada gambar } 4.5 \text { tokoh ibu } \\
\text { terlihat sebagai sumber kasih } \\
\text { sayang terhadap anaknya. Hal } \\
\text { ini bisa dilihat dengan bersenda } \\
\text { gurau bersama antara tokoh ibu } \\
\text { dengan tokoh anak. Bersedia } \\
\text { mendengarkan cerita tokoh } \\
\text { anak laki-laki menunjukkan } \\
\text { adanya kasih sayang dari tokoh } \\
\text { ibu. Salah satu tanda rasa kasih } \\
\text { sayang adalah kepedulian } \\
\text { terhadap lingkungan dalam } \\
\text { menciptakan kebahagiaan } \\
\text { (Sumartono, 2004). }\end{array}$ \\
\hline
\end{tabular}

Pada gambar 4.5 tokoh ibu menerima ajakan tokoh anak untuk bersenda gurau dan bercerita setelah bekerja. Menurut Fitriyani, Nunung dan Sahadi (2016) dalam penelitiannya menjelaskan kebutuhan dasar anak dari peran ibu adalah kebutuhan 
Website: https://ojs.unikom.ac.id/index.php/common

DOI Jurnal: https://doi.org/10.34010/common

DOI Artikel: https://doi.org/10.34010/common.v4i1.2253

emosional seperti hubungan yang hangat, erat dan menciptakan rasa percaya diri serta rasa aman. Dengan menjadi pendengar yang baik, maka tokoh anak laki-laki memiliki rasa nyaman dan bahagia dengan kehadiran tokoh ibu. Hal tersebut menunjukkan tokoh ibu memiliki rasa kasih sayang terhadap tokoh anak laki-laki. Alfred Kadushin dalam Asriyah, Budi M., dan Meilany (2016) juga menjelaskan dalam pemberian kebutuhan emosional berupa kasih sayang merupakan peran yang dilakukan oleh orang tua kepada anaknya.

Gambar 6.

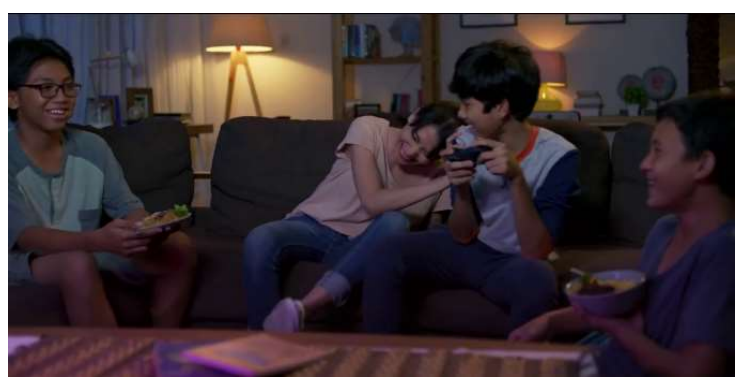

Tabel 6.

\begin{tabular}{|l|l|}
\hline \multicolumn{1}{|c|}{ Signifier Denotative } & \multicolumn{1}{|c|}{ Signified Denotative } \\
\hline $\begin{array}{l}\text { Scene tokoh ibu yang memeluk } \\
\text { tokoh anak iklan Supermi Hari } \\
\text { Ibu. }\end{array}$ & $\begin{array}{l}\text { Dalam scene tersebut, } \\
\text { penampilan tokoh ibu terlihat } \\
\text { berambut hitam dan } \\
\text { menggunakan baju berwarna }\end{array}$ \\
krem. Tokoh ibu sedang asik \\
bermain video game bersama \\
dengan tokoh anak laki-laki dan \\
teman dari tokoh anak. Tokoh \\
anak laki-laki terlihat berambut \\
pendek berwarna hitam dan \\
sedang memegang stick video \\
game dan menikmatinya. Tokoh \\
anak menikmati bermain video \\
game bersama tokoh ibu yang \\
ditandai dengan senyum \\
diwajahnya. Sedangkan kedua \\
tokoh teman tokoh anak laki- \\
laki sedang memegang \\
semangkuk mie. Mereka juga \\
ikut merasakan suasana yang \\
ceria yang ditunjukan dengan \\
senyum mereka. Semua tokoh \\
diatas berada di ruang keluarga.
\end{tabular}

\begin{tabular}{|l|l|}
\hline video game yang ditemani oleh & beserta teman-temannya. \\
teman tokoh anak laki-laki. & Meluangkan waktu yang \\
& dilakukan oleh tokoh ibu \\
& merupakan tanda rasa kasih \\
& sayang terhadap keluaganya. \\
& Menggunakan waktu bersama \\
& merupakan bukti kasih sayang \\
& (Djamarah, 2004). \\
\hline
\end{tabular}

Pada gambar 4.6 terlihat tokoh ibu meluangkan waktunya untuk bersama dengan tokoh anak laki-laki bersama dengan temannya. Meskipun tokoh ibu tahu bahwa tokoh anak laki-laki bersama temannya bermain game. Tokoh ibu tetap meluangkan waktunya untuk membersamai tokoh anak laki-laki. Hal ini menunjukkan bahwa tokoh ibu memiliki rasa kasih sayan. Tokoh ibu juga mampu menunjukkan kepada kedua teman tokoh anak laki-laki bahwa adanya kedekatan tokoh anak dengan tokoh ibu. Bukti kasih sayang dalam keluarga meliputi saling meluangkan waktu bersama keluarga, dan adanya komunikasi tiap anggota (Djamarah, 2004).

Mitos dalam scene-scene di atas adalah ibu merupakan sumber kasih sayang. Kasih sayang yang akan dilakukan oleh ibu untuk anaknya adalah berusaha meluangkan waktu untuk membersamai anaknya. Dalam Suryakusuma (2011) bahwa seorang ibu akan menjadi penyeimbang dalam keluarga. Seorang ibu akan memberikan rasa kasih sayang terhadap anaknya dengan cara menjadi pendengar dan komunikator yang baik. Seperti dalam Suryakusuma (2011) bahwa ibu akan mengajarkan anak tentang pengalaman-pengalaman yang dimilikinya untuk menumbuhkan kepribadian anak yang positif. Bentuk nilainilai tersebut berfungsi untuk melegitimasi domestifikasi bahwa ibu harus memenuhi kebutuhan emosional anak. Sehingga itu menjadi menjadi mitos yang dipercaya dimasyarakat bahwa ibu merupakan sumber kasih sayang. 
Website: https://ojs.unikom.ac.id/index.php/common

DOI Jurnal: https://doi.org/10.34010/common

DOI Artikel: https://doi.org/10.34010/common.v4i1.2253

\subsection{Ibu Sebagai Seorang yang Berperan Ganda}

Pada dasarnya, makna dari peran ganda perempuan adalah perempuan memiliki dua atau lebih peran atau fungsi yang harus dikerjakan dalam waktu yang bersamaan. Pembahasan ibu sebagai seorang yang berperan ganda, hanya berfokus pada peran kedua yang dilakukan oleh tokoh ibu dalam iklan. Peran ganda tersebut pada umumnya berkaitan dengan peran perempuan dalam ruang publik, yakni wilayah pekerjaan. Sedangkan peran yang lain adalah dalam ruang domestik, yakni sebagai ibu rumah tangga (Zuhdi, 2018).

Gambar 7.

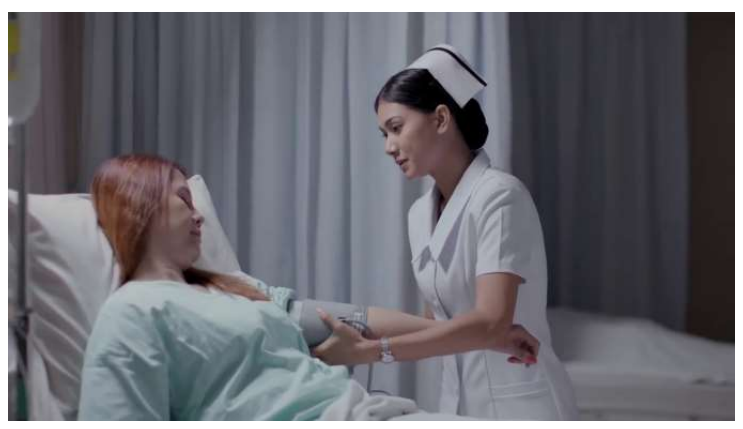

Tabel 7.

\begin{tabular}{|c|c|}
\hline Signifier Denotative & Signified Denotative \\
\hline $\begin{array}{l}\text { Scene tokoh ibu sedang } \\
\text { mengecek tensi darah seorang } \\
\text { pasien dalam iklan Johnson } \\
\text { Baby's. }\end{array}$ & $\begin{array}{l}\text { Tokoh ibu terlihat berambut } \\
\text { pendek hitam lurus dengan } \\
\text { model sanggul. Tokoh ibu } \\
\text { menggunakan seragam perawat } \\
\text { berwarna putih dengan topi } \\
\text { perawat berwarna putih dengan } \\
\text { corak garis hitam. Tokoh ibu } \\
\text { terlihat sedang melakukan tensi } \\
\text { darah kepada tokoh pasien. } \\
\text { Sedangkan tokoh pasien terlihat } \\
\text { berambut lurus panjang } \\
\text { berwarna coklat. Tokoh pasien } \\
\text { menggunakan baju pasien } \\
\text { berwarna biru muda dan sedang } \\
\text { tiduran. Scene di atas berada di } \\
\text { kamar pasien. }\end{array}$ \\
\hline Signifier Conotative & Signified Conotative \\
\hline $\begin{array}{l}\text { Selesai melakukan video call } \\
\text { dengan tokoh anak dan tokoh } \\
\text { ayah, tokoh ibu kembali } \\
\text { melanjutkan pekerjaannya. } \\
\text { Tokoh ibu mengambil papan } \\
\text { dan kertas medis, lalu menuju } \\
\text { ruang pasien. Di dalam ruang }\end{array}$ & $\begin{array}{l}\text { Dalam adegan di atas, tokoh ibu } \\
\text { termasuk sebagai seorang yang } \\
\text { berperan ganda. Terlihat jelas } \\
\text { dengan menjadi seorang } \\
\text { perawat, tokoh ibu tersebut } \\
\text { memiliki peran kedua, yakni } \\
\text { peran dalam wilayah pekerjaan. }\end{array}$ \\
\hline
\end{tabular}

pasien, tokoh ibu mengecek

tensi darah seorang pasien

dengan serius.

Pada gambar 4.7 tokoh ibu terlihat sebagai seorang perawat. Menjadi seorang perawat tentu harus melalui jalur pendidikan dibidang kesehatan. Hal ini menunjukkan sebuah pendidikan berpengaruh dalam peran ganda seorang perempuan. Dalam buku Kelompok Studi Wanita (1990) dijelaskan bahwa wanita yang berprofesi berasal dari yang golongan berpenghasilan rendah, tengah, atau atas. Golongan rendah menjelaskan bahwa mereka berprofesi guna menambah penghasilan keluarga mereka. Sedangkan golongan atas mempunyai alasan dengan adanya pendidikan yang sudah ditempuh guna mengembangkan dirinya.

Gambar 8

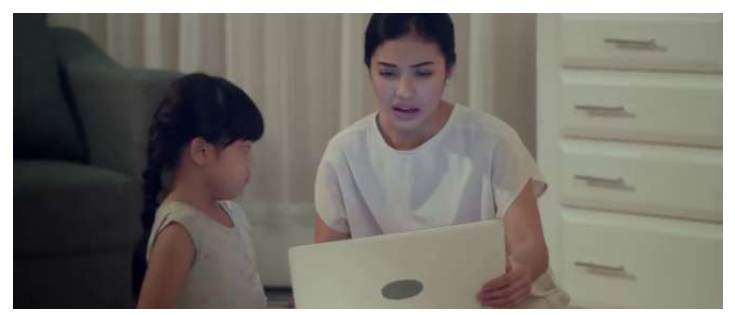

Tokoh anak perempuan sedang mengotak-atik laptop tokoh ibu, "Aku kerja juga, sama kayak mamah. Tokoh Ibu: eh.... sal. Kok dimainin sih?"

Tabel 8.

\begin{tabular}{|c|c|}
\hline Signifier Denotative & Signified Denotative \\
\hline $\begin{array}{l}\text { Scene tokoh ibu sedang } \\
\text { mengecek laptop setelah diotak- } \\
\text { atik oleh tokoh anak dalam iklan } \\
\text { Tupperware Indoensia. }\end{array}$ & $\begin{array}{l}\text { Scene di atas diambil dengan } \\
\text { menggunakan Medium Shot, } \\
\text { untuk menjelaskan detail. } \\
\text { Tokoh ibu memiliki rambut } \\
\text { panjang berwarna hitam dengan } \\
\text { model sanggul. Tokoh ibu } \\
\text { menggunakan kaos oblong } \\
\text { berwarna coklat muda dan } \\
\text { celana panjang berwarna putih. } \\
\text { Selanjutnya, tokoh anak } \\
\text { memiliki rambut panjang lurus } \\
\text { berwarna hitam dengan model } \\
\text { kepang dan menggunakan baju } \\
\text { berwarna putih sedang melihat } \\
\text { tokoh ibu. Dalam scene } \\
\text { tersebut, tokoh ibu sedang } \\
\text { memegang laptop berwarna } \\
\text { putih. }\end{array}$ \\
\hline
\end{tabular}


Website: https://ojs.unikom.ac.id/index.php/common

DOI Jurnal: https://doi.org/10.34010/common

DOI Artikel: https://doi.org/10.34010/common.v4i1.2253

\begin{tabular}{|c|c|}
\hline Signifier Conotative & Signified Conotative \\
\hline $\begin{array}{l}\text { Tokoh anak sedang meniru } \\
\text { tokoh ibu dengan menggunakan } \\
\text { laptop untuk bekerja, akan } \\
\text { tetapi tokoh ibu merasa kesal } \\
\text { ketika mengetahuinya. }\end{array}$ & $\begin{array}{l}\text { Berdasarkan dialog pada } \\
\text { gambar } 3.8 \text { dapat kita ketahui } \\
\text { kata "kerja" yang diucapkan } \\
\text { oleh tokoh anak menunjukkan } \\
\text { bahwa tokoh ibu juga berperan } \\
\text { dalam ruang publik. }\end{array}$ \\
\hline
\end{tabular}

Dalam gambar 4.8 tokoh anak perempuan mengatakan bahwa dirinya ingin bekerja seperti tokoh ibu. Hal ini menunjukkan bahwa tokoh ibu merupakan seorang yang berperan ganda. Wibowo (2011) menjelaskan bahwa pada umumnya peran ganda berkaitan dengan peran perempuan dalam ruang publik, yakni wilayah pekerjaan. Sedangkan peran yang lain adalah dalam ruang domestik, yakni sebagai ibu rumah tangga. Dalam era industrialisasi, tenaga kerja sangat diperlukan untuk proses produksi. Sehingga mengakibatkan bertambahnya lowongan kerja dan partisipasi wanita dalam angkatan kerja (Wibowo, 2011).

Gambar 9.

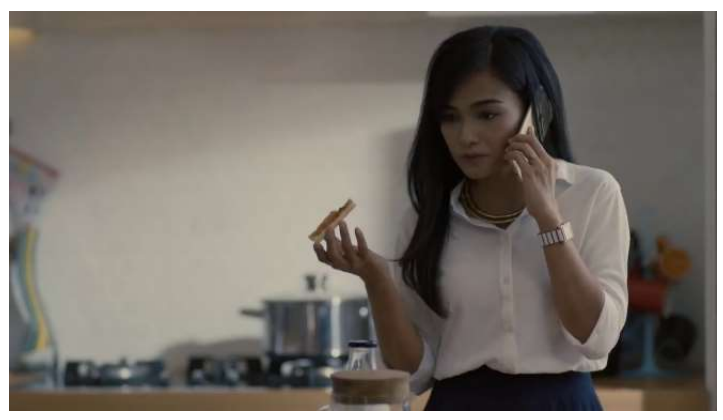

Tokoh ibu sedang menelpon, "Jam 1. Iya berarti habis makan siang kan? Ya kalau pun misalkan ada revisi kita masih ada waktu lah. Hmmm, iya.... bener".

Tabel 8.

\begin{tabular}{|c|c|}
\hline Signifier Denotative & Signified Denotative \\
\hline $\begin{array}{l}\text { Scene tokoh ibu sedang } \\
\text { menelpon dan memakan roti } \\
\text { dalam iklan Bukalapak video } \\
\text { hari ibu. }\end{array}$ & $\begin{array}{l}\text { Pada adegan ini tokoh ibu } \\
\text { terlihat berambut lurus } \\
\text { berwarna hitam panjang dengan } \\
\text { menggunakan kemeja warna } \\
\text { putih dan rok berwarna biru tua. } \\
\text { Tokoh ibu terlihat sedang } \\
\text { menelpon sambil memakan roti. } \\
\text { Tempat pada scene di atas } \\
\text { adalah dapur yang ditandai } \\
\text { dengan panci berwarna perak. }\end{array}$ \\
\hline Signifier Conotative & Signified Conotative \\
\hline
\end{tabular}

\begin{tabular}{|c|c|}
\hline $\begin{array}{l}\text { Sembari menunggu tokoh anak } \\
\text { laki-laki sarapan. Tokoh ibu } \\
\text { juga sarapan dengan memakan } \\
\text { roti sambil menelpon } \\
\text { seseorang tentang pekerjaan. }\end{array}$ & $\begin{array}{l}\text { Dalam gambar } 3.9 \text { tokoh ibu } \\
\text { terlihat sebagai seorang } \\
\text { pekerja. Hal ini ditunjukkan } \\
\text { dengan pakaian formal yang } \\
\text { digunakan oleh tokoh ibu. } \\
\text { Menurut Indrianti (2017) model } \\
\text { busana kerja wanita } \\
\text { diantaranya menggunakan blus, } \\
\text { rok, celana. }\end{array}$ \\
\hline
\end{tabular}

Pada gambar 4.9 tokoh ibu mengatakan melalui handphonenya bahwa dirinya akan melakukan revisi setelah jam 1 siang. Hal ini menujukkan bahwa tokoh ibu seorang pekerja dan terlihat dengan model busana kerja wanita yang dikenakannya. Mosse (2004) dalam Zuhdi (2018) menjelaskan bahwasanya perempuan memliki tiga peran, yakni peran dalam reproduksi, ekonomi produktif, dan manajemen komunitas. Hal ini menunjukkan bahwa pada dasarnya perempuan memiliki kapasitas dalam ruang publik untuk meraih kesejahteraan dalam mencair nafkah. Dalam bidang ekonomi telah dibantu oleh keikutsertaan perempuan yang telah di buktikan dalam laju peningkatan kerja antara tahun 1975-2017 lebih cepat dari peningkatan laju partisipasi pria (Zuhdi, 2018).

Mitos pada scene-scene di atas adalah seorang ibu yang berperan ganda merupakan peran seorang ibu. Perempuan yang memiliki pendidikan mempengaruhi peran ganda dan tidak hanya pada golongan rendah dan menengah, tetapi juga pada golongan atas. Dalam Suryakusuma (2011) perempuan yang juga memilih berperan di ruang publik dianggap juga sebagai sarana untuk aktualisasi diri dalam segi pendidikan. Seorang ibu yang berperan ganda adalah seorang ibu yang juga berkontribusi atau bekerja dalam membantu perekonomian keluarga. Seperti dalam Suryakusuma (2011) yang menjelaskan bahwa perempuan dianggap bertanggung jawab tidak hanya pada kesejahteraan psikologis para anggota rumah tangga, tetapi juga kesejahteraan material. Bentuk nilai-nilai tersebut 
Website: https://ojs.unikom.ac.id/index.php/common

DOI Jurnal: https://doi.org/10.34010/common

DOI Artikel: https://doi.org/10.34010/common.v4i1.2253

berfungsi untuk melegitimasi peran ganda perempuan. Sehingga itu menjadi menjadi mitos yang dipercaya dimasyarakat bahwa ibu yang berperan ganda merupakan peran dari seorang ibu.

\section{Kesimpulan dan Rekomendasi}

Berdasarkan iklan-iklan yang bertema hari ibu tahun 2017 menunjukkan adanya representasi peran ibu. Hal ini dijelaskan dari tiap kategori yang sudah peneliti lakukan. Ibu sebagai seorang pendidik merupakan peran ibu. Hal ini terlihat jelas dalam simbol-simbol mendidik seperti banyaknya waktu yang digunakan untuk mendidik dan mengawasi anak, ketika ibu menjadi pilar bagi anaknya dan membantu dalam kemandirian anak. Kedua, peran ibu sebagai sumber kasih sayang. Hal ini ditunjukkan melalui simbol-simbol kasih sayang seperti menjadi pendengar dan menjadi komunikator yang baik dan menyediakan waktu untuk bersama bersama anggota keluarga. Ketiga, peran ibu sebagai seorang yang berperan ganda. Hal ini ditunjukkan oleh simbol-simbol peran ganda seperti seorang ibu yang sekaligus bekerja dalam ruang publik dan bekerja untuk membantu perekonomian keluarga.

Dari keempat iklan yang diteliti dengan kategori peran yang peneliti buat, mengindikasikan bahwa iklan-iklan tersebut adanya paham ibuisme yang dijelaskan oleh Suryakusuma (2011) bahwa konsep ibu di negara Indonesia lebih dari sekedar keibuan bilogis, tetapi menyangkut perempuan yang bahkan tidak memiliki anak, perempuan yang memiliki keahlian, perempuan yang memiliki kedudukan sosial yang strategis, perempuan kaya, perempuan tua bisa disebut sebagai ibu. Konsep ibuisme tersebut menyiratkan pada nilai-nilai budaya, yang lingkupnya melebihi domestifikasi.
Tinjauan konsep ibusme dalam membahas peran ibu adalah usaha dalam menemukan peran ibu dalam iklan-iklan yang teliti pilih, hanyalah satu dari berbagai cara pemecahan. Penulis menyadari bahwa analisis dalam penelitian ini masih jauh dari kesempurnaan yang disebabkan oleh keterbatasan pengetahuan penulis. Adanya kekurangan dalam penelitian ini seperti kurang memaksimalkan waktu terkait objek dengan waktu selesainya penelitian, kurangnya pemilihan diksi yang tepat. Maka peneliti berharap adanya penelitian yang mengikuti perkembangan agar lebih bervariasi dan dapat menemukan lebih banyak lagi simbol-simbol terkait peran ibu. Penulis juga mengharapkan kekurangan tersebut dapat dilengkapi dan disempurnakan dengan penelitianpenelitian yang mengkaji ibuisme dalam media sehingga memenuhi apa yang diharapkan dan bermanfaat bagi perkembangan ilmu pengetahuan.

\section{Daftar Pustaka}

Afrida, Ervin. 2017. "Makna Konflik Peran Pada Mahasiswa Dengan Peran Ganda". Wahana.

Asriyah, dkk. (2016). Peranan Orang Tua Terhadap Perilaku Anak Sebagai Pemirsa Televisi Di Rumah. Prosiding KS: Riset \& PKM.

Budiman, Kris. 2011. Semiotika Visual: Konsep, Isu, dan Problem Ikonisitas. Yogyakarta: Jalasutra

Bungin, Burhan. 2013. Penelitian Kualitatif: Komunikasi, Ekonomi, Kebijakan Publik, dan Ilmu Sosial Lainnya. Jakarta: Prenada Media Group.

Djamarah, SB. 2004. Pola Komunikasi Orang Tua \& Anak Dalam Keluarga. Jakarta: Rineka Cipta 
Duverger, Maurice 2010. Sosiologi Politik. Jakarta: Rajagrafindo Persada.

Dwita, Desliana \& Wijayani Isna. 2018. "Gender Equality in Media Television (Semiotics Analysis of Fair and Lovely Advertisement Issue of Marriage Or Master Degree)". Komuniti.

Faiqah, F., Nadjib, M., \& Amir, A. S. 2016. "YouTobe Sebagai Sarana Komunikasi Bagi Komunitas Makassarvidgram". Jurnal Komunikasi KAREBA.

Firdaus, Muhammad Sandi. dkk. 2015. "Representasi Kapitalisme Dalam Film Snowpiercer (Analisis Semiotika Model John Fiske)". eProceeding of Management.

Firdyasari, Oktavia Eka. 2015. "Official Account Sebagai Iklan Di Sns (Motivasi Pemilihan Official Account Di Line)". Komuniti.

Fitriyani, Nunung dan Sahadi. 2016. "Peran Ibu Yang Bekerja Dalam Pemenuhan Kebutuhan Dasar Anak". Prosiding KS: Riset \& PKM.

Gunarsa \& Gunarsa. 2000. Psikologi Praktis: Anak Remaja dan Keluarga. Jakarta: PT. BPK Gunung Mulia.

Hall, Stuart. 2003. "The Work of Representation" Representation: Cultural Representation and Signifying Practices. London: Sage Publication.

Huda, Anam Miftakhul. 2016. "The Identity Of Javanese Women (The Study of Phenomenology Toward Indonesian Migrant Women Workers)". JARES.

Hyosymania, Darosy. 2011. "Peran Keluarga Dalam Membangun
Karakter Anak”. Jurnal Psikologi Undip.

Ida, Rachmah. 2001. "The Construction of Gender Identity in Indonesia: Between Cultural Norms, Economic Implications, and State Formation". Jurnal Masyarakat, Kebudayaan dan Politik.

Indrayanti \& Lisna. 2007. Analisis perkembangan statistik ketenagakerjaan: Laporan sosial Indonesia 2007. Jakarta: BPS

Indrianti, Pingki. 2017. "Analisis Gaya Busana Kerja Muslimah, Studi Kasus: Pekerjaan Sektor Formal di Kota Jakarta”. Jurnal Rupa.

Ismujihastuti R. A Granita Dwisthi \& Mahadian Adi Bayu. 2015. "Representasi wanita dalam sampul album raisa". e-Proceeding of Management.

Isnawan, Fuadi. 2018. "Analisa Tindak Pidana Pembunuhan Bayi (Infanticide) Di Wilayah Hukum Pengadilan Negeri Islam Sleman". Jurnal Yuridis.

Javandalasta, P. 2011. 5 Hari Mahir Bikin Film. Surabaya: Java Pustaka Group.

Liliweri, Alo. 2011. Komunikasi Serba Ada Serba Makna. Jakarta: Kencana.

Lisnawati, Iis. 2017. "Cerita Pendek "Nyanyian Daun Teh" Dalam Tinjauan Analisis Wacana Kritis". Jurnal Ilmiah Program Studi Pendidikan Bahasa dan Sastra Indonesia.

Mabruri, Anton. 2013. Manajemen Produksi Program Acara TV Format Acara Drama. Jakarta: PT. Grasindo. 
Moriarty, dkk. 2018. Advertising. Jakarta: KENCANA.

Muwarni, Endah. 2018. "Domestikasi Perempuan dalam Iklan Produk Perawatan Produk dan Anak". Sociae Polites.

Nafriandi. 2016. "Perempuan Di Ruang Publik Dalam Persfektif Hadi". Jurnal Ilmiah Kajian Gender.

Nida, Fatma Laili Khoirun. 2014. "Persuasi Dalam Media Komunikassi Massa". Jurnal Komunikasi Penyiaran Islam.

Novrinda, Nina, dan Yulidesni. 2017. Peran Orang Tua Dalam Pendidikan Anak Usia Dini Ditinjau Dari Latar Belakang Pendidikan. Jurnal Potensia. Vol. 2 No. 1

Nugroho, Sarwo. (2014). Teknik Dasar Videografi. Yogyakarta: CV ANDI OFFSET.

Prasetyo, dkk. 2016. Pengaruh Iklan Secara Online Terhadap Keputusan Pembelian (Survey Pada Mahasiswa Pengguna Produk Telkomsel Internet 4G Lte). Jurnal Administrasi Bisnis (JAB).

Putri, Dyah Purbasari Kusumaning dan Lestari, Sri 2015. Pembagian Peran Dalam Rumah Tangga Pada Pasangan Suami Istri Jawa. Jurnal Penelitian Humaniora.

Rahmawati, dkk. 2010. Bias Gender dalam Iklan Attack Easy di Televisi. Jurnal Ilmu Komunikasi.

Santrock, John W. 2007. Perkembangan Anak. Jakarta: Erlangga.

Setiawan, Velina Agatha. 2013. "Representasi Pluralisme Dalam Film“?” (Tanda Tanya)". Jurnal EKomunikasi.
Siswati, Endah. 2014. "Representasi Domestikasi Perempuan dalam Iklan”. Jurnal Komunikasi.

Sobur, Alex. 2009. Semiotika Komunikasi. Bandung: PT Remaja Rosdakarya.

Soemanagara, Rd. 2006. Strategic Marketing Communications, Konsep Strategis dan Terapan. Bandung: CV Alfabeta.

Sugiyono. 2012. Metode Penelitian Kuantitatif Kualitatif $R \& B$. Bandung: Aflabeta.

Sumartono. 2004. Komunikasi Kasih Sayang. Jakarta: PT. Elex Media Komputindo.

Suryakusuma, Julia. 2011. Ibuisme Negara: Konstruksi Sosial Keperempuanan Orde Baru. Depok. Komunitas Bambu.

Syahran, Ridwa. 2015. "Ketergantungan Online Game dan Penanganannya". Jurnal Psikologi Pendidikan \& Konseling.

Veg-Sala, Nathalie dan Roux Elyette. 2018. "Cross-Gender Extension Potential of Luxury Brands: A Semiotic Analysis". Journal of Product and Brand Management.

Vera, Nawiroh. 2014. Semiotika dalam Riset Komunikasi. Bogor: Penerbit Ghalia Indonesia.

Wibowo, Dwi Edi. 2011. Peran Ganda Perempuan dan Kesetaraan Gender. Nuwazah.

Wiratmo Liliek Budiastuti dan Gifari Mochamad. 2008. "Representasi perempuan dalam majalah wanita". Jurnal studi gender dan anak.

Wulansari, Dewi. 2009. Sosiologi Konsep dan Teori. Bandung: Refika Aditama. 
Jurnal Common | Volume 4 Nomor 1 | Juni 2020

Website: https://ojs.unikom.ac.id/index.php/common

DOI Jurnal: https://doi.org/10.34010/common

DOI Artikel: https://doi.org/10.34010/common.v4i1.2253

Zuhdi, Syaifuddin. 2018. "Membincang

Masyarakat Industri”. Jurnal Peran Ganda Perempuan Dalam Jurisprudence. 